\title{
Development of District Potential with a Fruit Agro-Tourism in Sumenep
}

\author{
Rusnani*, Ribut Santoso, Cholilul Chayati \\ Wiraraja University, Madura Islands - Indonesian
}

*Corresponding Author: Rusnani, Wiraraja University, Madura Islands - Indonesian

\begin{abstract}
The development of district potential with a fruit agro tourism model is a solution that is in accordance with the wishes of Sumenep District government which seeks to make Sumenep city become a tourist destination in Madura. The purpose of this program is to develop of district potential by finding fruit agro-tourism models, increasing farmers' income by deceiving the district potential, and adding value to Sumenep so that it attracts the tourists to visit. The stage of this program was mapped the location of fruit agro-tourism areas, identify plants that have the potential to be developed, and identify the needs of fruit agro-tourism development in the first year. Data collection is done trough observation, interviews, and data analysis carried out by observing objects about the potential of the district and described by explanation.
\end{abstract}

This stage determine the fruit base area in sub-districts in Sumenep by determining the location quotient $(L Q)$ method, determining the best location through consideration; synergy with government policies, facilities and infrastructure that support access to location. The result of this study have selected areas that have the potential to develop fruit agro-tourism is Batuan village in Sumenep. While the potential commodities for fruit agro-tourism are dragon fruit, serikaya fruit, melon fruit, watermelon fruit, orange fruit, water guava fruit, jackfruit, and guava fruit. The right fruit agro-tourism model is community based on fruit agro-tourism model so that it can use labor in the village.

Keywords: a fruit agro-tourism, district potential

\section{INTRODUCTION}

Suramadu Development had the aim and purpose of prospering the community around the area of Surabaya and Madura by having three feasibility according to economic, ecological and socio-cultural aspects. Suramadu development will bring a beneficial impact on the economic development of the Madurese community, of course, it must be followed by supporting efforts in improving the people's economy.

The previous research was the empowerment of community potential in Jambu Village, from the results of the research it was proven that the community has a lot of potential but needs to be developed in order to help improve the welfare of the community as well as those who help to optimize the existing potential. Through the development of village potentials with the fruit agrotourism model, it is expected to help optimize the empowerment of village potentials so that productivity increases and community incomes also increase. Sumenep is one of the cities in Madura that has tourism and agricultural potential, so that potential can develop, various efforts need to be made to support its development in order to improve society. Through Fruit Agrotourism will help develop the potential of the village and support the Sumenep Regency government to realize the city of Sumenep as a tourist destination in Madura.

Agro-tourism model is a model that combines several aspects of activities in agriculture and tourism as well as the environment. This activity contains several elements, namely elements of recreation that are characteristic of tourism, elements of education that are packaged in tourism activities and socioeconomic elements in this case agricultural development in rural areas which are used as the main destination for agro-tourism.

The object of this research is Batuan Village, which is located in the middle of a vast rice field and surrounded by hills. The selected plants are annual fruit plants namely dragon fruit and serikaya fruit which are superior fruit in Sumenep Regency and interspersed with fruits that can be harvested within 
a period of three months namely melons and watermelons to avoid the emptiness of the harvested fruit, because dragon fruit begins to bear fruit at the beginning of the season rain, serikaya bears fruit before the end of the rainy season while melons and watermelons bear fruit in the dry season.

\section{LITERATURE REVIEW}

Agro-tourism is a travel or tourism activity that combines tourism and agricultural activities with the aim of empowering the environment and improving the welfare of the farming community (Sucipta: 2001).

Agro-tourism is a recreational activity that refers to activities that visit farmers who are working on their farm so that tourists can see the process of breeding, planting, harvesting, and even processing processed products in the context of agribusiness activities.

Agro-tourism can be grouped into ecological tourism (eco-tourism), namely tourism activities that do not damage or pollute nature with the aim of admiring and enjoying the beauty of nature, animals, plants as educational facilities (Deptan: 2005). The development of ecological tourism and agrotourism adhere to the principles of:

1. Reducing negative impacts that can damage the nature and culture.

2. Providing learning to tourists about the importance of conservation.

3. Emphasizing the importance of responsible business in collaboration with elements of government and society to meet the needs of local residents and conservation.

4. Directing direct economic benefits for the purpose of conserving natural resources and protected areas.

5. Emphasizing the need for regional tourism zones and the arrangement and management of plants for tourism purposes.

6. Emphasizing the use of environmental and social based studies and reducing the negative impact on the environment.

7. Encourage efforts to increase economic benefits for the country, business people, and local communities around the region.

8. Convincing that the development of tourism does not go beyond.

9. Entrusting the use of energy sources, protecting wild plants and animals, and adapting to the natural and cultural environment.

\subsection{Agro-Tourism Development}

Several factors for agro-tourism to be successful in relation to attractions offered as attractions according to Syamsu et al (2001) were:

1. Scarcity

2. Naturalness

3. Uniqueness

4. Involvement of labor

5. Optimizing land use

6. Fairness and equity considerations

7. Regional arrangement

2.1.1. Components that Must be Met to Become a Tourism Area According to Spillane (1994) Are:

a. Attractions namely the expanse of gardens / agricultural land, natural beauty, parks, culture, and agricultural activities.

b. Facilities are facilities that are needed such as public facilities, telecommunications, hotels and restaurants.

c. Infrastructure, for example irrigation, communication networks, health facilities, transport terminals, electricity sources, energy and others. 
d. Transportation in the form of vehicles that can be used to transport tourists.

e. Hospitality, a facility that can assist in the medical handling of health posts.

\subsubsection{There Are Fruit Agro Tourism Activities:}

1. Arrangement of fruit cultivation in such a way that it becomes an attractive and fun fruit garden so that it has a high selling value.

2. Classifying annual fruit plants and monthly fruit crops,

3. Providing facilities for enjoying freshly picked fruit or in the form of processed fruit juices and others.

4. Providing Madura cuisine

5. Providing a means of selling community handicrafts in the form of Madura souvenirs.

6. Providing play facilities and infrastructure for children

7. Providing processed fruits in Sumenep Regency

8. Public facilities and other tourism facilities.

\subsection{Agro Tourism Management}

In the effort to empower and develop the potential of this agrotourism management village, it involves the farmers who own the land and the surrounding community in collaboration with the Regional Government and the private sector. Farmers in this case the land owners who are willing to be used as demonstration land or tourist attractions facilitated by the local government and private. Farmers are also the managers of land that are used as agrotourism, both as garden workers, employees, supervisors, guides and others.

Private investors are investors who want to work together and invest their capital in developing tourism objects in Sumenep Regency so that their development can be maximized. While the implementation of activities involves the community in the countryside and surrounding areas as workers in agricultural activities, as tour guides or other employees.

\subsection{Empowerment and Development}

Empowerment is the maximum utilization of the potential possessed. Empowerment according to Sasi Soetarso (2003) has two interrelated meanings, namely:

1. Increased ability, motivation and role of all elements of society to support all forms of social welfare efforts.

2. Utilization of community resources that have been enhanced in their abilities, motivations, and roles.

The level of farming, farmers are directed to be willing and able to allocate resources under their control as optimally as possible so as to increase their income and income, which is known as Tri Matra, namely integrated farming, integrated commodities, and integrated areas (Wardoyo: 1982; Mubiyarto: 1983)

\subsection{Village Potential and Village Development}

Village potential is a village-owned resource that can be used and developed to improve community welfare.

Based on the potential rural areas are divided into three namely:

1. High-potential village areas are found in areas with fertile agricultural land, flat topography, equipped with technical irrigation, the region's ability to develop is greater.

2. The village area has medium potential, has rather fertile land, uneven topography, partially technical and semi-technical irrigation. This region still has enough ability to develop. 
3. Village areas have low potential, have infertile agricultural land, rough topography (hills), water sources depend on rainfall. This region is difficult to develop.

\subsection{Development Prospect Analysis}

The Locational Quotient (LQ) method is one of the approaches to a basic economic model, relevant and can be used to identify the distribution of agricultural commodities, and can be used to determine potential locations.

The data obtained from the classification and classification are based on fruit crop area data. Data analysis was carried out through several stages as follows:

a. Insert data

Insert data series by subsector during the past year

b. Calculate the average value

The crop types, the average harvested area is calculated according to each commodity from all subsectors.

c. Calculate LQ

The final step in this stage is to calculate the LQ value. You do this by entering the notations obtained into the LQ formula, namely pi / pt as a numerator and Pi / Pt as the denominator (CRGPRT, 1985).

$$
\begin{aligned}
\mathrm{LQ}= & \underline{\mathrm{P}_{\mathrm{j}} / \mathrm{P}_{\mathrm{t}}} \\
& \mathrm{Pi} / \mathrm{Pt}
\end{aligned}
$$

$\mathrm{P}_{\mathrm{i}}=$ area of commodity $\mathrm{i}$ harvested area at the national level

$\mathrm{P}_{\mathrm{t}}=$ total area of harvest for commodity sub-sector $\mathrm{i}$ at the national level

LQ calculation results produce 3 criteria, namely:

1.LQ $>1$ meaning that the commodity is a basis or source of growth, has a

comparative advantage, the results can meet the needs of the region and

can also be exported outside the region.

2.LQ $=1$ commodity classified as non-base, has no comparative advantage, its production is only sufficient to meet the needs of the region itself.

3.LQ $<1$ classified as non-base commodities, their production cannot meet their own needs so it needs supplies from outside.

\section{RESEARCH METHODS}

This research is a qualitative research. This type of research is a survey research.

a. Data Source

- Primary data obtained directly from community leaders and residents

- Secondary data obtained from documents, books, scientific magazines, journals etc.

b. Data Collection Technique

- Interview with government officials, community leaders in Sumenep

- Observation to the area that is the object of research

c. Data Processing and Data Presentation Techniques: Data Editing, Coding, Tabulation Analysis

- Insert data by subsector

- Calculate the average value

- Calculates LQ 
d. The sampling technique uses purposive sampling, namely the determination of the sample adjusted to the needs of research in this case is the community figure, and the relevant apparatus is the party involved in handling tourism, while the community figure is the elder in the community. The population in this study is the people in Sumenep Regency.

e. Miles and Hubermen's Model Data Analysis Techniques

- Display data

- Conclution Drawing / Verification

\section{DISCUSSION}

The results of the Lokation Quotient (LQ) analysis of fruit plants in each district in Sumenep Regency as follows:

\subsection{Determination of Fruits Base District}

\subsubsection{Location Analysis}

To determine the fruit base zoning, in this study the Location Quotient (LQ) method is the most commonly used and relatively simple base economic method. Based on the calculation of LQ values in 27 sub-districts in Sumenep Regency, the highest LQ value is in Prasional District with a score of 15.842 while the lowest LQ value is owned by Saronggi District with a score of 0.160 (see Table 1). Based on the highest and lowest LQ values, it was determined that Pruruan District is a dragon fruit base region in Sumenep Regency and Saronggi District is determined as a non-dragon fruit base area under study.

LQ value of zero dragon fruit harvest area in Giligenting, Talango, Kalianget, Ganding, Gapura, Raas, Sapekan, Arjasa, Kangayan and Masalembu Subdistricts areas does not have a total share of dragon fruit harvest area on the harvested area. fruit plants in his district.

Table1. Nilai LQ Luas Panen Buah-Buahan Masing-masing Kecamatan di Kabupaten Sumenep

\begin{tabular}{|l|l|l|l|l|l|l|l|l|}
\hline Kecamatan & Buah Naga & Srikaya & Melon & Nangka & Jambu Air & Semangka & Jambu Biji & Jeruk \\
\hline Pragaan & 15,842 & 0,451 & 1,948 & 2,060 & 0,216 & 0,434 & 0,203 & 0,000 \\
\hline Bluto & 1,003 & 0,000 & 2,048 & 2,375 & 0,477 & 0,959 & 0,449 & 0,000 \\
\hline Saronggi & 0,146 & 7,203 & 0,217 & 0,515 & 0,111 & 0,224 & 0,105 & 0,162 \\
\hline Giligenting & 0,000 & 0,000 & 0,000 & 2,179 & 0,664 & 1,335 & 0,625 & 0,000 \\
\hline Talango & 0,000 & 1,214 & 4,027 & 2,437 & 0,193 & 0,387 & 0,181 & 0,300 \\
\hline Kalianget & 0,000 & 0,164 & 0,000 & 0,476 & 1,116 & 2,244 & 1,050 & 0,812 \\
\hline Sumenep & 0,281 & 0,039 & 0,412 & 0,113 & 2,066 & 0,817 & 1,944 & 0,000 \\
\hline Batuan & 0,433 & 0,000 & 8,881 & 0,139 & 1,165 & 0,681 & 1,096 & 0,946 \\
\hline Lenteng & 0,267 & 0,294 & 0,195 & 3,203 & 0,292 & 0,587 & 0,275 & 0,509 \\
\hline Ganding & 0,000 & 0,306 & 0,813 & 1,422 & 0,799 & 1,606 & 0,752 & 0,000 \\
\hline Guluk-Guluk & 0,929 & 0,000 & 4,444 & 0,333 & 0,893 & 1,796 & 0,841 & 1,949 \\
\hline Pasongsongan & 0,316 & 3,440 & 0,578 & 2,549 & 0,000 & 0,124 & 0,000 & 0,000 \\
\hline Ambunten & 0,772 & 0,000 & 0,960 & 0,669 & 1,386 & 1,394 & 1,305 & 0,000 \\
\hline Rubaru & 0,305 & 0,182 & 0,186 & 0,047 & 0,278 & 0,279 & 3,990 & 1,663 \\
\hline Dasuk & 0,000 & 0,016 & 0,210 & 0,964 & 1,273 & 1,009 & 1,198 & 4,146 \\
\hline Manding & 2,718 & 0,110 & 1,462 & 0,373 & 1,124 & 1,130 & 1,058 & 7,085 \\
\hline Batuputih & 0,454 & 0,063 & 0,830 & 0,847 & 1,240 & 1,247 & 1,167 & 2,165 \\
\hline Gapura & 0,125 & 0,017 & 0,638 & 0,125 & 4,400 & 0,450 & 0,055 & 0,000 \\
\hline Batang-Batang & 1,111 & 0,153 & 2,033 & 0,519 & 1,302 & 1,309 & 1,225 & 0,758 \\
\hline Dungkek & 0,147 & 0,020 & 0,268 & 0,186 & 0,206 & 4,350 & 0,345 & 0,100 \\
\hline Nonggunong & 1,449 & 0,200 & 0,000 & 0,676 & 1,359 & 1,366 & 1,279 & 0,988 \\
\hline Gayam & 0,000 & 2,625 & 0,000 & 0,635 & 0,744 & 0,748 & 0,700 & 6,494 \\
\hline Raas & 0,000 & 3,828 & 2,033 & 0,370 & 0,434 & 0,436 & 0,408 & 7,576 \\
\hline Sapeken & 0,000 & 0,551 & 0,000 & 0,622 & 1,354 & 1,361 & 1,275 & 0,909 \\
\hline Arjasa & 0,000 & 0,606 & 1,340 & 0,049 & 1,488 & 1,496 & 1,401 & 0,500 \\
\hline Kangayan & 0,000 & 0,799 & 2,651 & 0,097 & 1,359 & 1,366 & 1,279 & 0,000 \\
\hline Masalembu & 0,000 & 0,000 & 2,139 & 0,546 & 1,279 & 1,286 & 1,376 & 0,797 \\
\hline
\end{tabular}


Notes: $L Q$ value is obtained based on the harvested area of each commodity calculated using secondary harvest area data from the Central Statistics Agency; **: base region; ***: highest LQ value

The calculation of LQ value of fruit harvested area was obtained using the help of Microsoft Excel 2007 to make it easier to obtain the LQ value of dragon fruit's area in all Pruruan sub-districts in Sumenep Regency. The following is how to find the LQ value of fruit harvested area if using manual counting, Kecamatan Prisata Sumenep as an example, using common patern of LQ: $\boldsymbol{L} \boldsymbol{Q}_{i}=\frac{\boldsymbol{X}_{i}^{r} / \boldsymbol{X}^{r}}{\boldsymbol{X}_{i}^{n} / X^{n}} L Q=\frac{6,39 / 26}{8,66 / 568,74}$

$$
\mathrm{LQ}=15,824
$$

Note:

$\mathrm{i}=$ Dragon Fruit Commodity

$\mathrm{r}=$ Prasional District

$\mathrm{n}=$ Sumenep Regency

$\mathrm{X} \_\mathrm{i} \wedge \mathrm{r}=$ Extent of Harvest Area in Dragon Fruit Commodities in the Prasional District Area $=6.39$ hectares

$X \_i^{\wedge} n=$ Area of Harvest Commodity of Dragon Fruit in Sumenep Regency $=26$ hectares;

$\mathrm{Xr}=$ Total Crop Harvest Area in Sumenep City District Area $=8.66$ hectares;

$\mathrm{Xn}=$ Total Harvest Area in Fruits in Sumenep Regency $=568.74$ hectares .

Based on the manual calculation, it was found that the LQ in Pruruan District is 15.842. Based on the criteria for determining the commodity base using LQ which states that if an area has an LQ value of more than 1 (1) then the region is a calculated commodity base (Hendayana, 2003). Therefore, Prasional District is a dragon fruit base region because its LQ value is greater than one.

The LQ calculation in this study also calculates the LQ value of other commodities so that this research is not only to find out the dragon fruit base area but also to see the other fruit crop commodity base areas in Sumenep Regency. In Table 6. the complete LQ calculation results for each fruit crop commodity can be seen in all sub-districts in Sumenep Regency.

Based on Table 6. it can be seen that the base regions (having LQ values of more than 1) for each in Sumenep Regency are as follows:

1. Base of Naga Fruit: Pruruan, Manding, Nonggunong and Batang-Batang Districts

2. Srikaya Base: Saraonggi, Talango, Pasongsongan, Gayam and Raas Districts

3. Melons: Batuan, Prasional, Bluto, Talango, Manding, Guluk, Manding, Batang-Batang, Raas, Arjasa, Kangayan, and Masalembu Districts.

4. Jackfruit Base: Sub-districts of Bluto, Praga, Lenteng, Ganding, Talango, Pasongsongan, and Ganding.

5. Water Guava Base: Kalianget District, Batuan, ambunten, Dasuk, Manding, Batu Putih, Gapura, Batang-Batang, Nongunong, Sapeken, Arjasa

6. Watermelon Base: Ganding, Giligenting, Guluk-guluk, Ambunten, Giligenting, Dasuk Manding, Batu Putih, Dungkek, Nunggunong, Sapeken, Arjasa, Kangayan, Masalembu.

7. Guava Base: Kalianget District, Sumenep, Batuan, Ambunten, Rubaru, Dasuk, Manding, Batu Putih, Trunks, Saronggi, Talango, Kalianget, Dungkek, Nonggunong, Arjasa, Kangayan, Masalembu.

8. Orange Base: Kalianget District, Sumenep, Batuan, Ambunten, Rubaru, Dasuk, Batuputih, Gayam, Raas 
The seven commodity base regions show that each crop commodity has a minimum of four base regions. But from each of these crop commodities there is only one base region with the highest LQ value. In Table 6. it can be seen that the highest LQ value for the dragon commodity is in Prasional District $(15,842)$, melon commodity in Batuan District $(8,881)$, orange commodity in Raas District (7,576), Manding damages 97,085) and Seckaya commodity in Saronggi District. (7,203), and Guava commodity in Rubaru District (3,990), Water Guava commodity in Gapura district $(4,400)$, watermelon commodity in Dungkek District $(4,60)$, Jackfruit commodity in Lenteng District $(3,203)$

Determination of the best location for the development of fruit agro-tourism in Sumenep Regency is not only based on the calculation of the base area based on LQ but the research in this case uses several other considerations such as:

1. Synergy with local government policies

2. Supporting facilities and infrastructure

3. Access to location

Sinergi dengan kebijakan pemerintah Kabupaten Sumenep merupakan prioritas bagi peneliti oleh karena itu peneliti melakukan Focus Group Discussion (FGD) dengan melakukan pertemuan dengan tokoh kunci misalnya Dinas pertanian, Badan Perencanaan dan PembangunanDaerah, Dinas Pariwisata, ahli Planologi, Penyuluh Pertanian Lapanagan, Kepala Desa, Ketua Gabungan Kelompok Tani

The facilities and infrastructure available in the sub-districts that have the highest fruit base need to be considered. This is a consideration in choosing a fruit agro-tourism location. Judging from the results of the survey team, it turns out that Batuan Subdistrict has more supporting facilities and infrastructure such as being close to Puskesmas, sub-districts, police stations, water sources, mosques.

Accessibility is the ease of access to the location of fruit agro-tourism development. Batuan District has the best access compared to other districts because in addition to the wide infrastructure and good transportation facilities other supporting facilities are available such as being close to other attractions such as Sumekar Indah Park, Asta Tinggi, Museum, Kraton, Sumekar Water Park, Bukit Tinggi so that This is a positive consideration for choosing Batuan sub-district as a location for Fruit Agro Tourism.

\subsubsection{Potential Analysis}

Batuan Village Batuan Subdistrict has a land with agro-climate which is suitable for fruit plants because the rock village has a good and strategic natural panorama and is easily accessible from other tourist sites. Besides flora, mountains and extensive rice fields make a beautiful view, in terms of irrigation there is a large water source from the royal heritage so that irrigation will not be lacking.

Adequate infrastructure and infrastructure such as roads and transportation are quite a lot and the distance from the city is quite close, worship facilities, health center facilities, electricity, water, access to other tourist attractions very close so that it will facilitate tourists visiting.

\section{Conclusion, Suggestion, Results and Benefits}

\subsection{Conclusion}

Based on the studies that have been carried out, it can be concluded that:

1. Fruit Agrotourism has the potential to be developed in Batuan village, Batuan Sumenep subdistrict

2. Potential fruit plant commodities are dragon fruit, watermelon, melon, sugar apple, orange, jackfruit, water guava, guava.

3. The right fruit agro-tourism development model is developed with the community-based agrotourism model so that it can absorb the workforce that is still unemployed.

\subsection{Suggestion}

1. Further research is needed to analyze community perceptions and feasibility studies on the development of fruit agro-tourism in Sumenep Regency. 
2. The attention of the government to further empower the potential that exists in the village

\subsection{Results and Benefits}

From the results of the study concluded that

1. Fruit Agrotourism has the potential to be developed in Batuan village, Batuan District

2. Potential fruit plant commodities are dragon fruit, watermelon, melon, sugar apple, orange, jackfruit, water guava, guava.

3. The right model for developing Agro-tourism is Community-based Agro-tourism.

\subsubsection{Benefits of Research}

With the development of Fruit Agrotourism, the potential in the Village can be empowered as much as possible so that it can increase the income of rural communities and can improve community welfare.

\section{REFERENCES}

[1] Anwar Sanusi,2011. Metodologi Penelitian Bisnis,Salemba Empat,Jakarta

[2] Departemen Kebudayaan dan Pariwisata, 2009. Prinsip dan Kreteria Ekowisata

[3] Dewi Rachmawati, Rusdarti, Y. Titik Haryati., Strategy Development of Stroberial Fruit Agrotourism on Serang Village Farmers Income, Purbalingga District. Semarang. Journal of Economic Education. JEE 8 (1) $2019: 57-66$

[4] Gelgel, I Putu, 2009. Industri Pariwisata Indonesia Dalam Globalisasi Perdagangan Jasa. PT.Refika Aditama Bandung.

[5] I Ketut Sumantra, Anik Yuesti, AA. Ketut Sudiana., Development of Agrotourism to Support CommunityBased Tourism toward Sustainable Agriculture. Aust. J. Basic \& Appl. Sci., 11(13): 93-99, 2017

[6] Kusmayadi dan Enda Sugiarto. 2000. Metodologi Penelitian dalam Bidang Kepariwisataan. Jakarta : PT.Gramedia Pustaka Utama

[7] Moleong, Lexy J. 1994. Metodologi Penelitian Kualitatif. Bandung PT.Remaja Rosdakarya

[8] Miles, Matthew B dan A Michael Huberman 1992. Analisis Data kualitatif. Jakarta: Penerbit Universitas Indonesia. PS,2007.Agribisnis Tanaman Buah, Perbar Swadaya, Jakarta

[9] Sedarmayanti, 2014. Membangun dan Mengembngkan Kebudayaan dan Industri Pariwisata. PT.Refika Aditama Bandung.

[10] Singarimbun, Masri dan Sofyan Effendi. 1989. Metode Penelitian Survei. Jakarta PT Pustaka LP3ES Indonesia

Citation: Rusnani, Ribut Santoso, Cholilul Chayati. "Development of District Potential with a Fruit AgroTourism in Sumenep" International Journal of Managerial Studies and Research (IJMSR), vol 8, no. 8, 2020, pp. 66-73. doi: https://doi.org/10.20431/2349-0349.0808007.

Copyright: (C) 2020 Authors. This is an open-access article distributed under the terms of the Creative Commons Attribution License, which permits unrestricted use, distribution, and reproduction in any medium, provided the original author and source are credited. 